DOI: https://doi.org/10.24127/ajpm.v8i2.2128

\title{
EFEKTIVITAS PEMBELAJARAN PREVIEW, QUESTION, READ, REFLECT, RECITE, REVIEW DITINJAU DARI PEMAHAMAN KONSEP MATEMATIS
}

\author{
Agung Putra Wijaya ${ }^{1}$, Tina Yunarti ${ }^{2}$, Jamal Ludinsyah ${ }^{3}$ \\ ${ }^{1,2,3}$ Pendidikan Matematika FKIP Universitas Lampung \\ E-mail: $\quad$ agung.wijaya@fkip.unila.ac.id ${ }^{1)}$ \\ tina_yunarti@yahoo.com ${ }^{2}$ \\ jamal030197@ gmail.com $^{3)}$
}

Received 17 July 2019; Received in revised form 30 October 2019; Accepted 6 November 2019

\begin{abstract}
Abstrak
Penelitian ini bertujuan untuk mengkaji efektivitas metode pembelajaran Preview, Question, Read, Reflect, Recite, Review (PQ4R) ditinjau dari pemahaman konsep matematis siswa. Populasi penelitian ini adalah seluruh siswa kelas VII SMP Negeri 20 Bandarlampung semester genap tahun pelajaran 2018/2019 sebanyak 346 siswa yang terdistribusi ke dalam sebelas kelas. Dari sebelas kelas tersebut diambil satu kelas secara acak sebagai sampel penelitian. Penelitian ini menggunakan one-group pretestposttest design. Data penelitian diperoleh melalui tes berbentuk uraian pada materi Segiempat dan Segitiga. Analisis data penelitian ini menggunakan uji t berpasangan. Hasil penelitian menunjukkan pemahaman konsep matematis siswa setelah mengikuti pembelajaran dengan metode PQ4R lebih tinggi dibandingkan pemahaman konsep matematis siswa sebelum mengikuti pembelajaran dengan metode PQ4R namun persentase siswa yang memiliki pemahaman konsep terkategori baik tidak lebih dari $60 \%$ dari banyaknya siswa yang mengikuti pembelajaran metode PQ4R. Dengan demikian, metode PQ4R tidak efektif ditinjau dari pemahaman konsep matematis siswa.
\end{abstract}

Kata kunci: pemahaman konsep matematis; PQ4R

\begin{abstract}
This study aimed to find out the effectiveness of the Preview, Question, Read, Reflect, Recite, Review (PQ4R) learning method in terms of students' understanding of mathematical concepts. The population of this study was all seventh grade students of SMP Negeri 20 Bandarlampung in the even semester of the academic year of 2018/2019 as many as 346 students that distributed into eleven classes. The sample was taken randomly one class of the eleven classes as the study sample. This study used the one-group pretestposttest design. The research data was obtained through a essay test of the quadrilateral and triangle. Data analysis of this research used paired t-test. The results showed that students' undestanding of mathematical concepts after taking the PQ4R learning method was higher than students' understanding of mathematical concepts before taking the PQ4R learning method, but the percentage of students who had a good understanding of the mathematical concepts was not more than $60 \%$ of the number of students who took PQ4R learning. Thus, PQ4R method was not effective in terms of students' understanding of mathematical concepts.
\end{abstract}

Keywords: $P Q 4 R$; understanding of mathematical concepts

\section{PENDAHULUAN}

Pendidikan merupakan modal penting yang harus dimiliki oleh setiap individu, karena dengan pendidikan seseorang dapat menemukan potensinya sehingga mampu menjadi individu-individu yang berintelektual dan siap bersaing secara global. Hal ini sesuai dengan tujuan pendidikan nasional yang tercantum dalam Undang- 
Undang Republik Indonesia Nomor 20 tahun 2003 Bab 1 Ayat 2 tentang Sistem Pendidikan Nasional yang menyebutkan bahwa tujuan pendidikan nasional adalah mengembangkan kemampuan dan membentuk watak serta peradaban yang bermartabat dalam rangka mencerdaskan kehidupan bangsa dan untuk mengembangkan potensi siswa agar menjadi manusia yang beriman dan bertaqwa kepada Tuhan Yang Maha Esa, berakhlak mulia, sehat, berilmu, cakap, kreatif, mandiri, dan menjadi warga negara yang demokratis dan bertanggung jawab.

Dalam pendidikan, banyak mata pelajaran yang diajarkan, salah satunya adalah matematika. Matematika diajarkan pada setiap jenjang pendidikan. Oleh karena itu, keberhasilan siswa dalam mempelajari matematika adalah salah satu tolak ukur berhasilnya suatu pendidikan. Matematika menjadi pelajaran yang perlu diajarkan kepada siswa di sekolah. Seperti yang diungkapkan oleh Mutia (2019) bahwa alasan perlunya belajar matematika yaitu (1) matematika selalu digunakan dalam segala segi kehidupan, (2) semua bidang studi memerlukan keterampilan matematika yang sesuai, (3) matematika merupakan sarana komunikasi yang kuat, singkat, dan jelas, (4) matematika dapat digunakan menyajikan informasi dengan berbagai cara, (5) matematika dapat meningkatkan kemampuan berpikir logis, teliti, dan kesadaran akan keruangan, dan (6) matematika dapat memberikan kepuasan terhadap usaha untuk menyelesaikan masalah yang menantang.

Keberhasilan dalam mempelajari matematika dapat dilihat dari berkembangnya kemampuan kognitif dan psikomotor siswa. Hal ini sejalan dengan tujuan pembelajaran matematika yang tertuang dalam Lampiran Permendikbud No 58 Tahun 2014 yang salah satunya adalah siswa dapat memahami konsep matematika. Berdasarkan tujuan tersebut, pemahaman konsep merupakan hal penting yang harus dikuasai siswa, karena kemampuan ini menjadi dasar untuk dapat memiliki kemampuankemampuan lainnya dalam matematika.

Pemahaman konsep merupakan salah satu kemampuan yang harus dimiliki siswa dalam penguasaan materi pelajaran yang sedang diajarkan. Mawaddah dan Ratih (2016) mengemukakan bahwa pemahaman adalah suatu proses yang terdiri dari kemampuan untuk menerangkan dan menginterpretasikan sesuatu, mampu memberikan gambaran, contoh, dan penjelasan yang lebih luas dan memadai serta mampu memberikan uraian dan penjelasan yang lebih kreatif. Ainy (2009) menambahkan bahwa pemahaman konsep merupakan salah satu kecakapan atau kemahiran matematika yang diharapkan dapat tercapai dalam belajar matematika, yaitu dengan menunjukkan pemahaman konsep matematika yang dipelajarinya, menjelaskan keterkaitan antar konsep, dan mengaplikasikan konsep atau algoritma secara luwes, akurat, efisien, dan tepat dalam pemecahan masalah. Pemahaman konsep matematis penting untuk belajar matematika secara bermakna, tentunya guru mengharapkan pemahaman yang dicapai siswa tidak terbatas pada pemahaman yang bersifat dapat meng-hubungkan.

$$
\text { Pada Peraturan Menteri }
$$

Pendidikan dan Kebudayaan Nomor 58 tahun 2014 tentang Kurikulum 2013 Sekolah Mene-ngah Pertama/Madrasah Tsanawiah di-jelaskan bahwa pemahaman konsep me-rupakan salah 
tujuan penting dalam pem-belajaran matematika. Dengan memahami konsep, siswa akan lebih mudah untuk menyelesaikan masalah yang diberikan oleh guru. Pernyataan tersebut sejalan dengan pendapat Murniati, Candiasa, dan Kirna (2013) bahwa dengan pemahaman konsep siswa akan lebih mudah dalam memecahkan permasalahan karena siswa akan mampu mengaitkan serta memecahkan permasalahan tersebut.

Hasil Trend in International Mathematics and Science Study (TIMSS) tahun 2015 dalam bidang matematika menempatkan Indonesia pada peringkat ke-45 dari 50 negara dan hasil Programme for International Student Assesment (PISA) sebagaimana dipublikasikan oleh Nizam (2016) menempatkan Indonesia pada posisi ke62 dari 70 negara. Fakta ini menunjukkan bahwa prestasi matematika dalam skala internasional masih sangat rendah. Salah satu penyebabnya adalah masih lemahnya pemahaman konsep matematis siswa. Hal ini didukung oleh pendapat Mansur (2018) bahwa untuk dapat menjawab soal-soal yang diujikan oleh PISA dibutuhkan pemahaman yang baik terhadap konsep-konsep dalam matematika. Oleh karena itu, perlu diadakan perbaikan-perbaikan dalam pembelajaran matematika di sekolah. Guru harus selalu berusaha menemukan cara-cara pembelajaran yang dapat membantu siswa mencapai pemahaman konsep matematis yang optimal.

Rendahnya pemahaman konsep matematis juga dialami oleh siswa kelas VII SMPN 20 Bandarlampung. Hal ini dibuktikan dengan hasil analisis hasil ujian semester ganjil mata pelajaran matematika kelas VII SMPN 20 Bandarlampung tahun pelajaran 2018/2019 yang menunjukkan bahwa tidak ada satu pun siswa yang berhasil mencapai ketuntasan pada ujian semester ganjil, karena nilai kriteria ketuntasan minimal (KKM) yang telah ditetapkan oleh sekolah adalah 70,00. Lebih mendalam, data analisis daya serap yang dibuat oleh guru menjelaskan bahwa pemahaman konsep matematis siswa kelas VII SMPN 20 Bandarlampung pada sebagian besar materi matematika yang diajarkan guru di semester ganjil masih tergolong rendah. Hal ini diindikasikan dari lemahnya daya serap siswa pada setiap butir soal dalam ujian semester ganjil.

Tidak cukup melihat dari data tersebut, pada 24 Januari 2019 dilakukan pengamatan langsung pada pembelajaran matematika di kelas VII-I SMPN 20 Bandar Lampung. Pembelajaran dimulai guru dengan membagi kelas ke dalam 8 kelompok kecil. Pada awal pembelajaran, guru meminta siswa untuk membaca materi perbandingan pada bahan ajar yang telah disediakan. Sebagian siswa terlihat masih malas untuk membaca dan sibuk dengan kegiatan lain di dalam kelompoknya. Kemudian, guru menyam-paikan materi dengan menjelaskan konsep dan memberikan contoh yang relevan dengan konsep. Walaupun sekolah telah menerapkan Kurikulum 2013, namun pembelajaran masih berpusat kepada guru. Guru telah menerapkan model pembelajaran semi Team Games Tournament (TGT), hanya saja selama pembelajaran siswa masih terlihat pasif. Siswa hanya terlihat aktif pada sesi games dan pemberian reward saja. Hal ini terjadi karena kurang antusiasnya siswa dalam membaca materi pembelajaran, sehingga siswa cenderung terlihat bingung dalam menerima pembelajaran yang disampaikan oleh guru. 
Pada akhir sesi, guru memberikan soal latihan. Dari delapan kelompok, hanya satu kelompok yang dapat menjawab soal dengan benar. Dalam waktu relatif singkat, kelompok tersebut berhasil menyelesaikan soal yang telah diberikan dengan benar. Hanya saja, dari jawaban yang dituliskan, siswa belum mampu menerapkan konsep yang telah diajarkan dalam memecahkan masalah. Untuk mengujinya, guru meminta siswa tersebut untuk menyatakan ulang kembali jawaban dan siswa mengalami kesulitan untuk mengungkapkan jawabannya. Dari tujuh kelompok lainnya, enam kelompok menjawab soal dengan kurang tepat dan satu kelompok tidak mampu dalam menjawab soal.

Melihat permasalahan tersebut, perlu dilakukan upaya untuk memperbaiki dan meningkatkan mutu pembelajaran mate-matika. Dalam proses pembelajaran, membaca menjadi kegiatan yang paling mendasar yang harus dilakukan oleh siswa untuk mengetahui informasi yang belum diketahui sebelumnya. Kemampuan seseorang dalam membaca adalah bagian penting yang tidak terpisahkan dari kemampuan literasi. Literasi matematika merupakan hal yang sangat penting dalam pemahaman konsep matematis siswa. Hal ini dikarenakan menurut OECD dalam Masjaya dan Wardono (2018), literasi matematika merupakan kemampuan mencakup penalaran matematis dan kemampuan menggunakan konsep-konsep matematika, prosedur, fakta, dan fungsi matematika untuk menggambarkan, menjelaskan, dan memprediksi suatu fenomena. Dalam Kurikulum 2013, literasi matematika merupakan kemampuan yang diperlukan oleh setiap siswa dalam mencapai tujuan pembelajaran. Hal ini didasarkan dari hasil penelitian Syahlan (2015) yang menjelaskan bahwa untuk mencapai tujuan pendidikan yang mengacu kepada Standar Kompetensi Lulusan (SKL), kompetensi inti, dan kompetensi dasar matematika, serta mengacu pada standar penilaian diperlukan literasi matematika dalam proses pembelajaran matematika.

Salah satu metode yang paling banyak dikenal untuk membantu siswa memahami dan mengingat materi yang mereka baca adalah metode PQ4R (Preview, Question, Read, Reflect, Recite, Review) yang dipelopori oleh Thomas dan Robinson pada tahun 1972. Menurut Sopiawati (2015), metode PQ4R ini meliputi enam tahap yang berkesinambungan yaitu (1) preview yaitu membaca (judul, subjudul, topik, kalimat pertama) selintas dengan cepat sebelum memulai membaca, (2) question yaitu mengajukan pertanyaanpertanyaan kepada diri sendiri mengenai bahan bacaan yang akan dibaca, (3) read yaitu mulai untuk membaca sambil mengingat pertanyaan yang sudah dibuat, (4) reflect yaitu selama membaca siswa mencari jawaban atas pertanyaan yang sudah dibuat dan memahami informasi yang ada pada bacaan tersebut, (5) recite yaitu merenungkan informasi yang telah dipelajari dari hasil bacaan dengan cara membuat intisari dari bacaan, dan (6) review yaitu membaca intisari yang telah dibuat.

Hasil penelitian yang telah dilakukan oleh Marnita (2018), AlQawabeh dan Aljazi (2018), Indrawati, Riyadi, dan Matsuri (2014), Wahono (2014) menyimpulkan bahwa metode PQ4R efektif meningkatkan pemahaman siswa dalam membaca. Selain itu, hasil penelitian yang dilakukan oleh Pratiwi, Yusrizal, dan Elisa (2016) dan Wondal (2016) 
menyimpulkan bahwa metode PQ4R mampu meningkatkan hasil belajar IPA siswa. Hasil-hasil penelitian tersebut menunjukkan metode PQ4R mampu meningkatkan pemahaman konsep siswa melalui aktivitas membaca bahan ajar yang disediakan oleh guru. Melalui aktivitas membaca ini, siswa mampu mengonstruksi pemahamannya sehingga meningkatkan pemahaman konsep terhadap materi yang dipelajarinya.

Penelitian sebelumnya telah menerapkan metode PQ4R pada pembelajaran bahasa dan IPA dasar dan belum pernah diterapkan pada pembelajaran yang menuntut siswa untuk melakukan aktivitas berhitung, seperti matematika. Mata pelajaran matematika juga dapat diajarkan melalui penyediaan bahan ajar bagi siswa. Penerapan metode PQ4R pada pembelajaran matematika diharapkan efektif ditinjau dari pemahaman konsep matematis siswa kelas VII SMPN 20 Bandarlampung. Oleh karena itu, perlu dilakukan penelitian dengan tujuan untuk mengkaji efektivitas metode PQ4R ditinjau dari pemahaman konsep matematis siswa.

\section{METODE PENELITIAN}

Penelitian ini merupakan penelitian eksperimen semu. Populasi penelitian ini adalah seluruh siswa kelas VII SMPN 20 Bandar Lampung tahun pelajaran 2018/2019 sebanyak 346 siswa yang terdistribusi ke dalam 11 kelas yaitu kelas VIIA-VIIK. Pengambilan sampel dilakukan dengan teknik cluster random sampling. Berdasarkan proses sampling, diperoleh siswa kelas VIIF sebagai sampel. Sampel bertindak sebagai kelas eksperimen yaitu kelas yang menggunakan metode pembelajaran PQ4R.
Penelitian tentang efektivitas metode PQ4R ditinjau dari pemahaman konsep matematis siswa ini terdiri dari satu variabel bebas dan satu variabel terikat. Dalam penelitian ini, yang menjadi variabel bebas adalah metode PQ4R dan yang menjadi variabel terikatnya adalah pemahaman konsep matematis. Penelitian ini menggunakan one-group pretest-posttest design yang hanya menggunakan satu kelas eksperimen untuk diberi tes awal dan tes akhir.

Penelitian ini dilakukan dalam tiga tahapan yaitu tahap persiapan, tahap pelaksanaan, dan tahap akhir. Tahap persiapan telah dilaksanakan pada 24 Januari sampai dengan 09 maret 2019, tahap pelaksanaan telah dilaksanakan pada 04 April sampai dengan 09 Mei 2019, dan tahap akhir telah dilaksanakan pada 10 Mei sampai dengan 10 Juli 2019.

Data penelitian ini berupa nilai pemahaman konsep matematis siswa yang diperoleh dari hasil tes awal (pretest), tes akhir (posttest), dan perbedaan (different) hasil tes awal dan tes akhir. Pengumpulan data penelitian ini menggunakan teknik tes. Materi yang digunakan pada tes awal adalah garis dan sudut, sedangkan materi yang digunakan pada tes akhir adalah segiempat dan segitiga.

Instrumen tes yang digunakan berbentuk uraian yang disusun dengan memperhatikan indikator pemahaham konsep matematis sebagai berikut: (1) menyatakan ulang konsep yang telah dipelajari, (2) mengklasifikasikan objek-objek berdasarkan dipenuhi tidaknya persyaratan yang membentuk konsep tersebut, (3) mengidentifikasi sifat-sifat operasi atau konsep, (4) menerapkan konsep secara logis, (5) memberikan contoh atau bukan contoh dari konsep yang dipelajari, 
menyajikan konsep dalam berbagai macam bentuk representasi matematis, (7) mengaitkan berbagai konsep di dalam maupun luar matematika, dan (8) mengembangkan syarat perlu dan/ atau syarat cukup suatu konsep.

Sebelum digunakan untuk mengumpulkan data, terlebih dahulu dilakukan uji validitas. Uji ini didasarkan pada expert judgment dari guru mata pelajaran matematika di SMPN 20 Bandar Lampung. Selain itu, dilakukan uji coba soal pada siswa kelas VIII yang hasilnya dianalisis untuk mengetahui validitas, reliabilitas instrumen, daya pembeda, dan tingkat kesukaran butir soal.

Validitas instrumen yang digunakan dalam penelitian ini didasarkan pada validitas isi. Uji validasi ini dilakukan dengan menggunakan lembar check list. Hasil validasi menunjukkan bahwa instrumen tes yang digunakan untuk mengambil data awal dan akhir pemahaman konsep matematis telah memenuhi validitas isi.

Analisis terhadap hasil uji coba menunjukkan bahwa instrumen tes awal memiliki reliabilitas tinggi dengan koefisien reliabilitas sebesar 0,61 dan instrumen tes akhir memiliki reliabilitas sangat tinggi dengan koefisien reliabilitas sebesar 0,81. Semua instrumen tes telah memiliki daya pembeda baik dan sangat baik (dengan indeks berkisar antara 0,32 sampai 0,86 ) dan tingkat kesukaran yang sedang dan sukar (dengan indeks berkisar antara 0,29 sampai 0,68).

Sebelum melakukan uji hipotesis, dilakukan uji prasyarat yaitu uji normalitas. Uji normalitas ini dilakukan untuk melihat apakah data perbedaan (different) dan data nilai akhir pemahaman konsep matematis siswa berasal dari populasi berdistribusi normal atau tidak. Dalam penelitian ini, uji normalitas yang digunakan adalah uji Lilliefors dengan taraf signifikan $\alpha=$ 0,05. Dari hasil perhitungan uji normalitas data perbedaan (different) pemahaman konsep matematis diperoleh $L_{0}=0,0915$ dan hasil perhitungan uji normalitas data nilai akhir pemahaman konsep matematis diperoleh $L_{0}=0,1081$. Oleh karena $L_{\text {tabel }}=0,1591$. maka $L_{0}<L_{\text {tabel }}$, sehingga $\mathrm{H}_{0}$ diterima. Dengan demikian, data perbedaan (different) dan data nilai akhir pemahaman konsep matematis berasal dari populasi berdistribusi normal. Berdasarkan hasil tersebut, pengujian hipotesis penelitian dilakukan dengan menggunakan uji $\mathrm{t}$ berpasangan dan uji proporsi.

\section{HASIL PENELITIAN DAN PEMBAHASAN}

Data pemahaman konsep matematis diperoleh dari hasil tes awal (pretest) dan tes akhir (posttest). Berdasarkan hasil pengumpulan data, diperoleh data pemahaman konsep matematis siswa seperti yang disajikan dalam Tabel 1.

Tabel 1. Data Pemahaman Konsep Matematis

\begin{tabular}{lccc}
\hline Data & Tes & Tes & \multirow{2}{*}{ Different } \\
Penelitian & Awal & Akhir & \\
\hline Minimum & 0,00 & 23,94 & 21,50 \\
Maksimum & 57,41 & 88,73 & 61,97 \\
Rata-rata & 21,45 & 53,57 & 32,09 \\
Simpangan & 20,51 & 16,58 & 20,65 \\
Baku & & & \\
\hline
\end{tabular}

Dari Tabel 1 terlihat bahwa nilai ratarata tes akhir pemahaman konsep matematis lebih tinggi dibandingkan nilai rata-rata tes awal pemahaman konsep matematis dengan rata-rata different sebesar 32,09. Simpangan baku data akhir pemahaman konsep matematis lebih rendah dibanding-kan 
dengan simpangan baku data awal pemahaman konsep matematis. Hal ini menunjukkan bahwa penyebaran data awal pemahaman konsep matematis lebih beragam dibandingkan dengan data akhir pemahaman konsep matematis siswa.

Selanjutnya dilakukan pengujian hipotesis. Berdasarkan hasil perhitungan uji $\mathrm{t}$ berpasangan, diperoleh $\mathrm{t}_{\text {hitung }}=$ 2,13 dengan $t_{\text {tabel }}=1,70$. Oleh karena $\mathrm{t}_{\text {hitung }}>\mathrm{t}_{\text {tabel }}$ maka $\mathrm{H}_{0}$ ditolak, yang berarti pemahaman konsep matematis siswa sebelum mengikuti pembelajaran metode PQ4R tidak sama dengan pemahaman konsep matematis siswa setelah mengikuti pembelajaran metode PQ4R. Oleh karena $\mathrm{H}_{0}$ ditolak, maka selanjutnya dilakukan uji lanjutan dengan membandingkan rata-rata nilai awal pemahaman konsep matematis dengan rata-rata nilai akhir pemahaman konsep matematis. Berdasarkan hasil analisis data pemahaman konsep matematis, bahwa rata-rata nilai akhir pemahaman konsep matematis $(\bar{x}=$ $53,57)$ lebih tinggi dibandingkan ratarata nilai awal pemahaman konsep matematis $(\bar{x}=21,45)$. Hal ini berarti pemahaman konsep matematis siswa setelah mengikuti pembelajaran dengan metode PQ4R lebih tinggi dibandingkan pemahaman konsep matematis sebelum mengikuti pembelajaran dengan metode PQ4R.

Kemudian, dilakukan uji proporsi satu pihak. Berdasarkan data pemahaman konsep matematis siswa setelah mengikuti pembelajaran dengan metode PQ4R diperoleh 19 siswa yang memiliki pemahaman konsep matematis terkategori baik dari 31 siswa yang mengikuti pembelajaran dengan metode PQ4R. Berdasarkan hasil perhitungan uji proporsi satu pihak, diperoleh $z_{\text {hitung }}=0,15$ dengan $z_{\text {tabel }}=1,65$. Oleh karena $\mathrm{z}_{\text {hitung }}<\mathrm{z}_{\text {tabel }}$ maka $\mathrm{H}_{0}$ diterima, yang berarti persentase siswa yang memiliki pemahaman konsep terkategori baik tidak lebih dari $60 \%$ dari jumlah siswa yang mengikuti pembelajaran metode PQ4R.

Selanjutnya, dilakukan analisis pencapaian tiap indikator pemahaman konsep matematis pada tes awal dan tes akhir pemahaman konsep matematis siswa yang disajikan pada Tabel 2 .

Tabel 2. Persentase Pencapaian Indikator Pemahaman Konsep Matematis

\begin{tabular}{ccc}
\hline Indikator & $\begin{array}{c}\text { Tes Awal } \\
(\mathbf{\%})\end{array}$ & $\begin{array}{c}\text { Tes Akhir } \\
(\mathbf{\%})\end{array}$ \\
\hline A & 28,23 & 62,15 \\
B & 15,05 & 58,06 \\
C & 16,85 & 53,76 \\
D & 33,33 & 73,79 \\
E & 37,63 & 73,12 \\
F & 15,05 & 53,76 \\
G & 21,51 & 41,13 \\
H & 11,83 & 33,87 \\
\hline Rata-rata & 22,44 & 56,21 \\
\hline
\end{tabular}

Keterangan:

A : Menyatakan ulang konsep yang telah dipelajari

B : Mengklasifikasikan objek-objek berdasarkan dipenuhi tidaknya persyaratan yang membentuk konsep tersebut

$\mathrm{C}$ : Mengidentifikasi sifat-sifat operasi atau konsep

D : Menerapkan konsep secara logis

E : Memberikan contoh atau bukan contoh dari konsep yang dipelajari

$\mathrm{F}$ : Menyajikan konsep dalam berbagai macam bentuk representasi matematis

$\mathrm{G}$ : Mengaitkan berbagai konsep di dalam maupun luar matematika

$\mathrm{H}$ : Mengembangkan syarat perlu dan/atau syarat cukup suatu konsep

Berdasarkan Tabel 2, persentase pencapaian setiap indikator pemahaman konsep matematis siswa setelah 
mengikuti pembelajaran dengan metode PQ4R lebih tinggi dibandingkan sebelum mengikuti pembelajaran dengan metode PQ4R. Hal ini menjelaskan bahwa setelah mengikuti pembelajaran metode $\mathrm{PQ} 4 \mathrm{R}$, siswa dapat menyatakan ulang konsep yang telah dipelajari, mengklasifikasikan objek-objek berdasarkan dipenuhi tidaknya persyaratan yang membentuk konsep tersebut, mengidentifikasi sifatsifat operasi atau konsep, menerapkan konsep secara logis, memberikan contoh atau bukan contoh dari konsep yang dipelajari, menyajikan konsep dalam berbagai macam bentuk representasi matematis, mengaitkan berbagai konsep dalam matematika maupun di luar matematika, dan mengembangkan syarat perlu dan/atau syarat cukup suatu konsep menjadi lebih baik.

Pada awal pembelajaran, guru menjelaskan metode PQ4R dan aturan main pembelajaran pada siswa. Untuk menstimulus keaktifan siswa, guru menerapkan pemberian penghargaan berupa pemberian bintang kepada siswa yang aktif, dan menyampaikan akan diumumkan peraih bintang kelas bagi yang paling banyak mendapatkan bintang. Sontak semangat belajar siswa menjadi meningkat dan terlihat begitu antusias untuk aktif dalam pembelajaran. Hal ini sejalan dengan hasil penelitian Suyuti (2017) yang menjelaskan bahwa pemberian penghargaan berupa kata-kata pujian, pemberian isyarat seperti jempol, tepuk tangan, tulisan pada tugas siswa, dan pemberian nilai tambahan untuk siswa semakin memotivasi siswa untuk belajar.

Melihat siswa yang mulai antusias dalam pembelajaran, guru memberikan apersepsi berupa pertanyaan kepada siswa. Pertanyaan tersebut berbunyi, "Coba kalian sebutkan, benda-benda di kelas ini yang merupakan segiempat?", seketika hampir semua siswa mengangkat tangan dan meneriakkan "saya pak!", Oleh karena terlalu banyak siswa yang mengangkat tangan, guru meminta mengulanginya kembali, dan memberikan aba-aba berupa hitungan kepada siswa yang ingin menjawab.

Setelah suasana kelas dipenuhi dengan semangat berkompetisi antar siswa, guru kemudian membagikan bahan ajar yang telah disiapkan pada setiap meja belajar siswa. Guru meminta setiap siswa untuk membaca sekilas sub materi yang ada pada bahan ajar, tujuannya agar siswa mengetahui materi yang akan mereka pelajari dan menimbulkan pertanyaan-pertanyaan dari sub materi yang mereka baca, sehingga dapat meningkatkan interaksi siswa dengan siswa atau siswa dengan guru. Hal ini sesuai dengan hasil penelitian Munawaroh (2018) yang menjelaskan penerapan teknik membaca sekilas pada kemampuan memahami teks dapat menciptakan interaksi aktif antar siswa dengan guru atau siswa dengan siswa.

Setelah itu, guru meminta siswa untuk membuat pertanyaan terkait sub materi yang telah mereka baca pada buku catatan. Pertanyaan-pertanyaan yang timbul pun beragam dari siswa, oleh karenanya guru ikut mengarahkan mem-berikan pertanyaan-pertanyaan pokok kepada siswa. Selanjutnya, guru meminta siswa untuk membaca isi setiap sub materi secara bertahap, tujuannya agar siswa tidak mudah jenuh dalam pembelajaran. Pada tahap ini, kondisi siswa sesuai dengan yang diharapkan guru, sebagian besar siswa semangat membaca bahan ajar untuk menggali informasi sehingga mereka dapat menjawab pertanyaan. Pada tahap 
ini siswa bukan hanya diminta untuk membaca, tetapi juga merefleksikan pemahamannya terhadap apa yang mereka baca

Pada tahap recite (merenung), siswa diminta untuk merenungkan pemahamannya dan untuk mengukur pemahaman siswa, guru melemparkan pertanyaan-pertanyaan pokok kepada siswa dengan mengimingi pemberian bintang kepada mereka yang dapat menjawab pertanyaan. Sama halnya seperti pemberian apersepsi, pertanyaan yang diberikan oleh guru dengan cepat disambar oleh siswa, dan membuat suasana kelas menjadi ramai oleh antusias siswa menjawab pertanyaan. Melalui alat peraga berupa sedotan, guru mencoba meluruskan pemahaman siswa mengenai definisi dari setiap jenis segiempat, dan guru juga meminta siswa menyebutkan kembali pemahaman konsep mereka melalui alat peraga yang diberikan oleh guru. Kemudian di akhir pembelajaran, guru meminta siswa untuk mereview kembali materi yang telah mereka pelajari.

Pada pertemuan kedua, ketiga, keempat, dan kelima antusias siswa mengalami penurunan, berbeda dengan pertemuan pertama. Hal ini disebabkan karena materi yang mereka pelajari memerlukan analisis perhitungan, yang berbeda dengan pertemuan pertama yakni materi yang diajarkan masih bersifat teoritis. Meski demikian, bukan berarti siswa tidak aktif dalam pembelajaran, hanya saja keaktifan di kelas hanya ditunjukkan oleh siswa yang memiliki pemahaman konsep sedang, dan tinggi. Setiap tahap dalam metode PQ4R, secara umum dilalui dengan baik oleh siswa. Hanya saja pada saat proses berpikir 4R (Read, Reflect, Recite, Review), beberapa siswa yang memiliki pemahaman konsep terkategori rendah membuat suasana kelas menjadi kurang kondusif dengan membuat kegaduhan dan menggangu temannya yang aktif dalam pembelajaran. Untuk mengatasinya guru melakukan beberapa treatment, yakni dengan menegur langsung, membesarkan volume suara sehingga diperhatikan, dan memberikan pertanyaan-pertanyaan kepada siswa yang membuat kegaduhan.

Hasil penelitian ini sesuai dengan hasil penelitian oleh Marnita (2018), Al-Qawabeh dan Aljazi (2018), Indrawati, Riyadi, dan Matsuri (2014), Wahono (2014), Pratiwi, Yusrizal, dan Elisa (2016) dan Wondal (2016) yang menunjukkan adanya peningkatan pemahaman konsep siswa setelah menerapkan metode PQ4R. Hanya saja, hasil penelitian ini menunjukkan bahwa jika proporsi siswa yang memiliki pemahaman konsep terkategori baik tidak lebih dari $60 \%$. Tidak optimalnya tahap recite (merenung) saat pelaksanaan pembelajaran dalam penelitian ini membuat pemahaman siswa tidak optimal. Oleh karena itu, hendaknya guru dapat memberikan perhatikan khusus saat tahap recite untuk memastikan bahwa tidak ada siswa yang melakukan aktivitas off task. Hal ini dapat dilakukan guru berkeliling kelas atau mendekati siswa siswa yang melakukan aktivitas off task dan menegurnya agar melakukan tahap recite dengan baik.

\section{KESIMPULAN DAN SARAN}

Berdasarkan hasil analisis data dan pembahasan, diperoleh kesimpulan bahwa metode pembelajaran PQ4R tidak efektif ditinjau dari pemahaman konsep matematis siswa. Meskipun pemahaman konsep matematis siswa setelah mengikuti pembelajaran dengan metode PQ4R lebih tinggi dibandingkan pemahaman konsep matematis sebelum 
mengikuti pembelajaran dengan metode PQ4R, tetapi persentase siswa yang memiliki pemahaman konsep terkategori baik tidak lebih dari $60 \%$ dari banyaknya siswa yang mengikuti pembelajaran metode PQ4R.

Adapun saran yang dapat disampaikan berdasarkan hasil penelitian ini adalah bagi praktisi pendidikan yang ingin menerapkan metode pembelajaran PQ4R, hendaknya memberikan perhatian khusus pada tahap recite (merenung) untuk menjamin tidak ada siswa yang melakukan aktivitas off task dalam pembelajarannya. Dalam pelaksanannya, hendaknya tahap ini dapat dilalui dengan baik untuk meresapi pemahaman yang diperoleh dalam pembelajaran.

\section{DAFTAR PUSTAKA}

Ainy, C. (2009). Strategi Meningkatkan Pemahaman Konsep dan Kemampuan Komunikasi Matematika. Didaktis. Vol. 8 No. 3 Hal. $1-67$.

Al-Qawabeh, R. H. \& Aljazi, A. A. (2018). The Effectiveness of Using PQ4R Strategy in Teaching Reading Comperehension in Arabic Language Subject among Ninth Grade Students' Achievement in Jordan. World Journal of Educational Research. Vol. 5 No. 2 Hal. 159 - 171.

Depdiknas. (2003). Undang-Undang RI No.20 Tahun 2003 Tentang Sistem Pendidikan Nasional. Jakarta: Depdiknas.

Indrawati, T., Riyadi, \& Matsuri. (2014). Pengaruh Metode Pembelajaran Preview, Question, Read, Reflect, Recite, and Review (PQ4R) Terhadap Kemampuan Membaca

Pemahaman.
Dikdaktika Dwija Indria. 2(9), 16.

Kemendikbud. (2014). Peraturan Menteri Pendidikan dan Kebudayaan Nomor 58 Tahun 2014 Tentang Kurikulum 2013 SMP/MTs. Jakarta: Kemendikbud.

Mansur, N. (2018). Melatih Literasi Matematika Siswa dengan Soal PISA. Prisma. 1(1), $140-144$.

Marnita. (2018). The Effect of Using PQ4R (Preview, Question, Read, Reflect, Recite, Review) Strategy on EFL Students' Reading Comprehension Achievement. Research in English and Education Journal 3(1), 17 - 24.

Masjaya \& Wardono. (2018). Pentingnya Kemampuan Literasi Matematika untuk Menumbuhkan Kemampuan Koneksi Matematika dalam Meningkatkan SDM. Prisma 1(1), 568 - 574.

Mawaddah, S. \& Ratih, M. (2016). Kemampuan Pemahaman Konsep Matematis Siswa SMP dalam Pembelajaran Menggunakan Model Penemuan Terbimbing (Discovery Learning). EDU-MAT Jurnal Pendidikan Matematika. 4(1), 76 - 85.

Munawaroh, B., Madyono, S., \& Suwarti. (2018). Teknik Membaca Sekilas (Skimming) dalam Meningkatkan Kemampuan Memahami Narasi. Wahana Sekolah Dasar. 26(1), 7 - 12.

Murniati, L. D., Candiasa, I. M., \& Kirna. (2013). Pengembangan Perangkat Pembelajaran Matematika Realistik untuk Meningkatkan Kemampuan Pemecahan Masalah Siswa SMP. Jurnal Pendidikan dan Pengajaran. 46(2), $114-124$.

Mutia. (2019). Analisis Kesulitan Belajar Matematika Siswa SMP 
DOI: https://doi.org/10.24127/ajpm.v8i2.2128

Kelas IX dalam Memahami Konsep Tabung dan Alternatif Pemecahannya dengan Pendekatan Pemecahan Masalah. Jurnal Equation. 2(1). 1 - 21.

Nizam. (2016). Ringkasan Hasil-Hasil Asesment Belajar Dari Hasil UN, PISA, TIMSS, INAP/AKSI. Jakarta: Kemendikbud.

Pratiwi, A. D., Yusrizal, Y., \& Elisa, E. (2016). Pengaruh Penggunaan Strategi Pembelajaran PQ4R (Preview, Question, Read, Reflect, Recite, Review) terhadap Hasil Belajar Siswa pada Materi Gerak Kelas VII SMP Negeri 1 Baitussalam. Jurnal Ilmiah Mahasiswa Pendidikan Fisika Unsiyah 13(2), 131- 141.

Sopiawati, I. (2015). Penerapan Strategi PQ4R (Preview, Question, Read, Reflect, Recite, and Review) dalam Pembelajaran Comprehension Ecrite IV. Barista 2(1), $1-19$.
Suyuti, R. N. R. (2017). Pemberian Reward dan Punishment dalam Rangka Meningkatkan Hasil Belajar Siswa. Jurnal Sosialisasi Pendidikan Sosiologi - FIS UNM 4(1), $82-86$.

Syahlan. (2015). Literasi Matematika dalam Kurikulum 2013. Jurnal Pendidikan, Pemikiran, dan Pengabdian. 3(1), 36 - 43.

Wahono, S. S. (2014). Using PQ4R to Increase The Students' Reading Comprehension at Al-Bidayah Islamic Boarding School. Fenomena. 13(2), 121 - 131.

Wondal, R. (2016). Penggunaan Model Pembelajaran Preview, Questions, Read, Reflect, Recite, Review (PQ4R) untuk Meningkatkan Aktivitas dan Hasil Belajar Biologi. Jurnal Pendidikan Dasar UNJ. 7(1), $128-139$. 